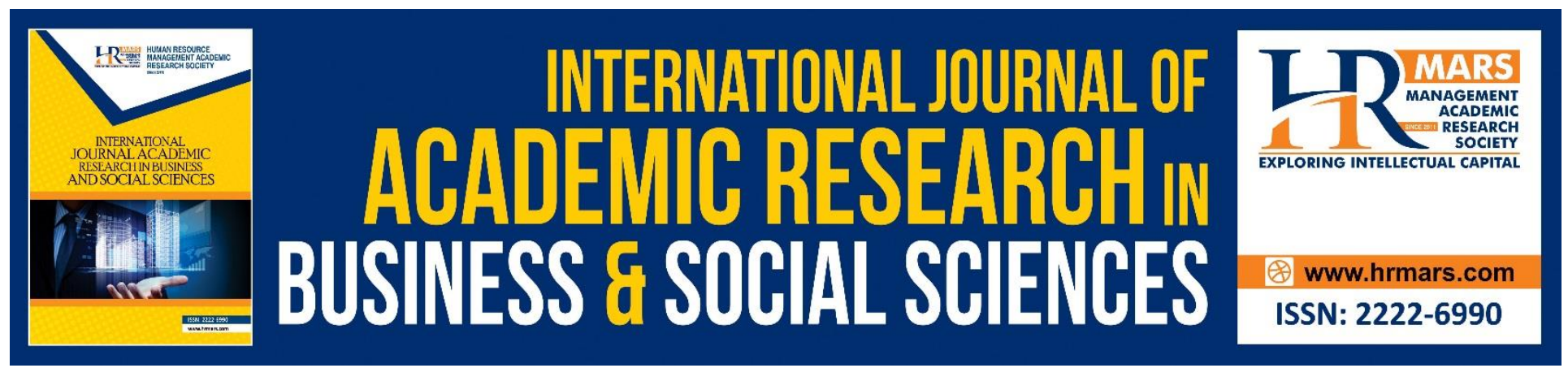

\title{
Revolutions of Mural Painting
}

Norfarain Abd Rahman, Abd Rasid Ismail, Ruslan Abdul Rahim

To Link this Article: http://dx.doi.org/10.6007/IJARBSS/v10-i10/8279 DOI:10.6007/IJARBSS/v10-i10/8279

Received: 08 August 2020, Revised: 05 September 2020, Accepted: 27 September 2020

Published Online: 24 October 2020

In-Text Citation: (Rahman et al., 2020)

To Cite this Article: Rahman, N. A., Ismail, A. R., \& Rahim, R. A. (2020). Revolutions of Mural Painting. International Journal of Academic Research in Business and Social Sciences, 10(10), 1195-1200.

Copyright: () 2020 The Author(s)

Published by Human Resource Management Academic Research Society (www.hrmars.com)

This article is published under the Creative Commons Attribution (CC BY 4.0) license. Anyone may reproduce, distribute, translate and create derivative works of this article (for both commercial and non-commercial purposes), subject to full attribution to the original publication and authors. The full terms of this license may be seen at: http://creativecommons.org/licences/by/4.0/legalcode

Vol. 10, No. 10, 2020, Pg. 1195 - 1200 http://hrmars.com/index.php/pages/detail/IJARBSS JOURNAL HOMEPAGE

Full Terms \& Conditions of access and use can be found at http://hrmars.com/index.php/pages/detail/publication-ethics 


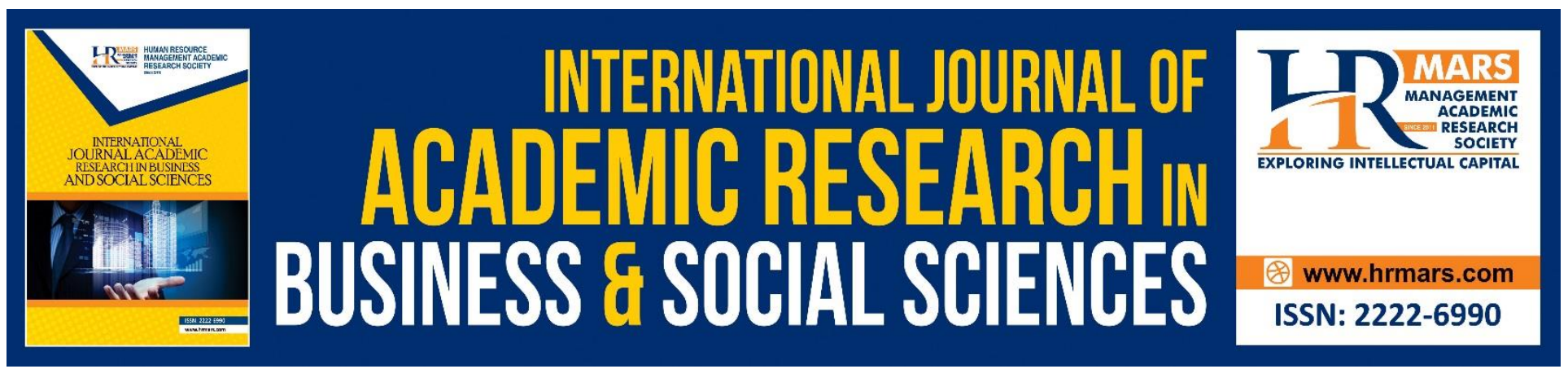

\title{
Revolutions of Mural Painting
}

\section{Norfarain Abd Rahman, Abd Rasid Ismail, Ruslan Abdul Rahim}

Department of Graphic Design, Faculty of Art and Design, Universiti Teknologi MARA, Malaysia Department of Fine Art, Faculty of Art and Design, Universiti Teknologi MARA, 40450 Shah Alam, Selangor, Malaysia

\begin{abstract}
Mural painting is a decorative art on the walls of the building in order to convey messages to the society. The purpose of this study is to emphasize the sequence of mural paintings, in particular those related to elements in the design and types of murals corresponding to previous ones, and also to explore the background of murals based on previous mural paintings, originating with prehistoric cave paintings. Thus, understanding, recognizing and learning the context of past mural paintings can be as valuable as the present-day society. Moreover, the previous mural painting may be a perfect example and an inspiration for local artists to improve their ideas in terms of the style of application of the elements and the concept of mural painting. Thus, these mural paintings can be designed in a constructive manner and may provide both the artists and the universal society a strong and inspiring aesthetic value.
\end{abstract}

Keywords: Revolution, History Mural Painting, Graphic Design, and Fine Art.

\section{Introduction}

At the beginning, the development of the arts of drawing is related to the growth of human society. Language system and human surviving styles in the past, such as hunting, trapping, farming and belief, were among the elements that inspired the arts of drawing. These influences were shown in the existence of artifacts, storytelling and narratives contained in those aspects. During these periods, drawing arts were used primarily as a means of reporting (in the form of a shape) for rewinding objective. Their pre-historic practices were often filled with drawing and painting. Communication through photos and images eventually formed a writing system where alphabets emerged and were later moderated and standardized.

Creation of art transpires when the process of making art takes place. The point here is why do painters or artists create art? Societies or publics from all around the world have learned and developed the arts since the dawn of human civilization. They make art for various motives and interpretations. Besides that, some artists will begin to make artworks and obtain the idea when it comes from mind with purpose. Being artists, they would often recognize essential items or much of the elements that may be included in their artworks. They are motivated by the surroundings that affect them to create a concept of building such an artwork. For instance, people and nature are important factors in the creation of idea or inspiration. It depends on whom they speak, what they 
INTERNATIONAL JOURNAL OF ACADEMIC RESEARCH IN BUSINESS AND SOCIAL SCIENCES Vol. 10, No. 10, 2020, E-ISSN: 2222-6990 @ 2020 HRMARS

practice and experience, what they believe, what they like nor dislike or even what they eat and drinks, and last but not least how they live. Artists are really determined to make every attempt to accomplish the one fine thing in their life. When ideas come, the creative part automatically will follow. The choice of subject matter in each painting is also an important resource for painters or artists. This is the tool where the symbol comes in. Some artists or painters use symbols in their masterpiece to tell the story, convey issues or significant topic to gathered the information. Most of the symbols are chosen by a painter whom relates to nature, but some of them may use social issues, politics and climate change.

In Malaysia, the use of symbols in their masterpiece is to communicate a message as a means of expression on a particular topic or issue. According to Mohamed, 2017 stated The art is an expression of a fundamental element which relates to human real life by observing how it interacts with objects, culture, society, and so forth. Therefore, the nature of becoming an artist is responsible of showing the essence of the world through their ability to share the experiences with audience. Furthermore, to evoke people's emotion also need to attempt the influence, world experiences and aesthetics of human lives.

The word 'mural' derived from the Latin word 'Murus' coming from the wall. According to the contemporary dictionary definition, mural is characterized as a large-scale drawing which is painted on either an interior or exterior wall. According to Golan (2009) in his book entitled Muralnomad: The Paradox of Wall Painting, Europe 1927-1957, murals are clarified in a moderate manner, indicating the peace of their personalities, which are positioned a few centimeters away from the wall. It is also a technique that can create illusions because it can broaden perceptions and instinctive elements that ultimately produce dreams and fantasies (Cass, 2002).

Murals had started as early as $3000 \mathrm{BC}$ which was obviously before the modern civilization. This is a prehistoric painting on the cave wall between Mira, known to be the earliest visual art in the Palaeolithic period due to its distinct artistic styles originating from the Spanish and Southern France districts. (Janson, 1962).

\section{The History of Murals}

The presence of murals has been documented for thousands of years, proving the ways and methods used to convey messages or stories of former lifestyles or habits. Until today, history and their delivery means have been used by researchers for research purposes. According to a book entitled Art in History, History in Art by David Freedberg and Jan de Vries, (1991), this phenomenon is reflective of past civilizations which have become much more prosperous. Hence, as we switch progressively from reading to seeing and activating the sensory organs towards world history, it has become more visual.

The history of mural paintings was first using hunted animals which were shown by drawing, carving and shaping the surface of walls in the cave. In the early days, mural painters were mainly pre-historic cavemen who painted caves with various cave paintings. These arts have defined past human practices, such as Ritual Dance, which have been performed in a moderate manner. Among the famous examples are found in Chauvet Cave, Vallon-Pont-d'Arc, France during 30,000 BC, Lascaux Cave, Montignac, Dordogne, France 17,000 BC and the last one is in Altamira Cave, Santillana del Mar, Spain that in known as the 'Pre-historic history of the Sistine Chapel'. 

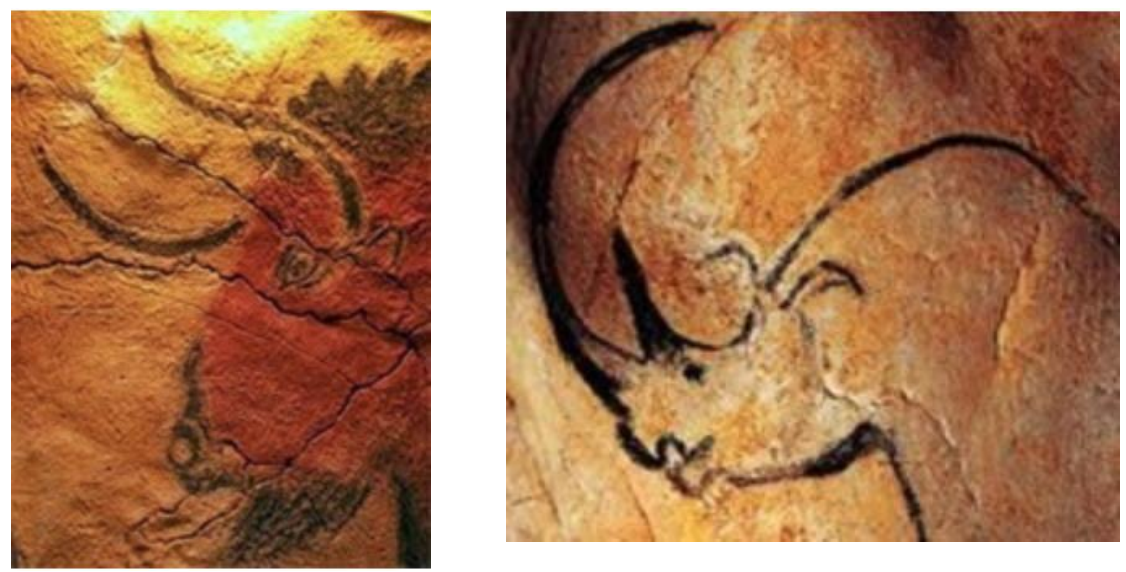

Polychrome cave paintings from bison heads $(15,000 \mathrm{BCE})$, The main cave gallery of Galeri Altamira. Big Horn Rhino (25-30,000 BCE) Cave paintings from Chauvet Cave. See: Art Age of Oldest Stone.

Murals are one of the most famous arts during the classical period which was also used by the Egyptians for their tombs, Minos (castle), old Greek (temples, houses), Etruria (funeral arts) and Old Roman (public institutions, houses). Nevertheless, the typical mural paintings found in Pompei, the Romans' mural painters, were much more than the interior decorators. Murals were also widely known art among Christians, particularly in the graveyards outside Rome.

Due to the fall of Rome in the fifth century, the art of murals was also faded in Europe for several decades, keeping the only Constantinople in the capital of the Eastern Roman Empire. The best murals from the Byzantine arts, however, appeared as the mosaic arts in churches and mosques such as Hagia Sophia (Constantinople), Ravenna Cathedral, St Mark's Cathedral, Venice and others. In the 10th century, Kiev became popular with the murals of the middle-century from Russia, and among the popular wall painters at that period were Theophanous the Greek (c.1340-1410), Rublev (c.13601430) and Dionysius (c.1440-1502).

In the 11th and 12th centuries, Western Europe witnessed the re-emergence of murals through Romanesque paintings in France, which possessed a national style based on the Islamic ideas of Spain. In the 14th, 15th and 16th centuries, the collapse of the Constantinople period and the emergence of the Renaissance in Florence, funded by the Medici, brought along beautiful murals paintings.

In the East, India was a nation that is rich with the traditions of mural paintings in the 1150 century such as the Classical Indian and Post-Classical Indian paintings in the $14^{\text {th }}$ century.

\section{Mannerist Murals}

Among the most well-known Mannerist mural paintings were the Last Judgement Fresco designed between 1536-1541, the Altar Wall of Sistine Chapel by Michelangelo and wall paintings by Francesco Primaticcion in Fontainebleu School between 1504-1570 as well as Rosso Fiorentino between the years 1494-1540.

\section{Baroque Murals}

During the Baroque period, the use of new perceptions and the technique of foreshortening created larger-scale murals, covering techniques such as 'sotto di su,' which means 'seen from the bottom' 
INTERNATIONAL JOURNAL OF ACADEMIC RESEARCH IN BUSINESS AND SOCIAL SCIENCES Vol. 10, No. 10, 2020, E-ISSN: 2222-6990 @ 2020 HRMARS

and 'quadrature'. Two examples of mural paintings are from Pietro da Cortona through his "Allegory of Divine Providence" between 1633-1639 and Andrea Pozzo between 1688-1694 in San Ignazio, Rome through his "Apotheosis of St Ignatius."

\section{Rococo Murals}

Around 1696 to 1770, the best wall paintings were painted by Venereian Giambattista Tiepolo which can be found in Wurzburg Residenz of Prince Bishop Karl Philipp von Greiffenklau. Other than that, the 1750's paint Apollo Bringing the Bride can be found in the middle of Trepenhaus' ceilings. All these mural paintings have had a significant effect to the closing of mural arts in Italy.

\section{Modern Mural Arts}

The walls of famous public buildings were certainly associated to painters, including the modern era, such as the Quinta del Sordo (Villa for the Deaf) in 1819-1823, located at the Manzanares River near Madrid. The painter, Goya, designed a series of murals known as "Black Drawing" and "Saturnus Delivering its Child" in the Prado Museum, Madrid. In 1806-1870, Daniel Maclise painted murals on the walls of Westminster Palace and John Singer Sargant painted murals for the Boston Public Library and the Widener Memorial Library at Harvardln 1863-1923 Joaquion Sorolla Y Bastida, who was a Spain Impressionist painter, died nine years after completing his murals for The Hispanic Society of America in New York. However, some artists have made great progress with their murals, particularly the famous French artist Chavannes (1824-98), who established his fame through the decoration of several public buildings in Paris, including the Pantheon, the Sorbonne as well as the de Ville Hotel. Nevertheless, mural paintings during the modern period are the two highest points, particularly when the first mural painters Mexico Diego Rivera (1886-1957), Siqueiros (1896-1974) and Orozco (18831949) brought together the re-emergence of public paintings in Mesoamerica. This had somehow influenced the use of murals in the USA by the School of Social Realism in the 1930s and 1940s, mainly by the social painter Ben Shahn (1989-1969). These American art decorations are typically made for public buildings under the command of the Federal Arts Project. Secondly, the enhancement of graffiti (street or aerosol arts) that developed in America, especially in Philadelphia and subsequently in New York, became the basis for contemporary art in major cities. Among the prominent graffiti artists in New York were Basquiat (1960-1988), Haring (1958-1990) and David Wojnarowics (19541992) and, later in the 1980s, Graham Rust and Rainer Maria Latzke, while in the 1990s, Banksy and Robert Banks, also recognized as Robin Gunningham. The main exhibition "Art Street" was held at the Tate Gallery in London (2008) and the Grand Palais in Paris (2009).

\section{Conclusion}

In conclusion, the history of this mural painting can continue to thrive with quality when the concepts and ideas applied are comparable to the thoughts of universal society in the current era of circulation. Thus, the outcome of ancient mural paintings has shown their logical proofs and ideas that any events that happen is a testament to the future generations.

\section{Corresponding Author}

Norfarain Abd Rahman

Department of Graphic Design Faculty of Art and Design Universiti Teknologi Mara, 40450 Shah Alam, Selangor, Malaysia 
INTERNATIONAL JOURNAL OF ACADEMIC RESEARCH IN BUSINESS AND SOCIAL SCIENCES Vol. 10, No. 10, 2020, E-ISSN: 2222-6990 @ 2020 HRMARS

Email: norfarainabdrahman@yahoo.com

\section{References}

Book

Cass, C. (2002). Grand Illusions, Contemporary Interior Murals, Oxford. Phaidon Press.

Freedberg, D., \& Vries, J.V (1991). Art in history, History in Art. Getty Center for the History of Art and the Humanities.

Golan, R. (2009). MuralNomad The Paradox of Wall Painting, Europe 1927-1957. Yale University Press New Haven \& London.

Seligman, P. (1987). Painting Murals, Images, Ideas and Techniques, North America in 1988. North Light Books 1507 Dana Avenue, Cincinnati, Ohio 